\title{
PERBANDINGAN NILAI SOSIAL DALAM NOVEL IVANNA VAN DIJK DENGAN NOVEL ANANTA PRAHADI KARYA RISA SARASWATI MELALUI PENDEKATAN SOSIOLOGI SASTRA
}

\author{
Agung Nugroho ${ }^{1} \&$ Yasafiq $^{2}$ \\ ${ }^{1}$ Program Studi Pendidikan Bahasa Indonesia, STKIP PGRI Lubuklinggau \\ ${ }^{2}$ STAI Miftahul Ulum Mukomuko \\ Jalan Mayor Toha, Kelurahan Air Kuti, Kota Lubuklinggau, Indonesia \\ Email: agung.nugroho12354@gmail.com, shavicgade@gmail.com
}

\begin{abstract}
Abstrak
Tujuan penelitian ini untuk mengambarkan perbandingan novel Ivanna Van Dijk karya Risa Saraswati dengan novel Ananta Prahadi karya Risa Saraswati melalui pendekatan sosiologi sastra. Metode penelitin ini adalah metode penelitian deskriptif kualitatif. Data penelitian adalah data yang berwujud kata-kata, ungkapan frasa atau kalimat yang menunjukkan nilai sosial dalam novel Ivanna Van Dijk Karya Risa Saraswati dengan novel Ananta Prahadi karya Risa Saraswati. Teknik analisis data dengan cara reduksi data, penyajian data, dan penarikan kesimpulan. Hasil penelitian menunjukkan bahwa novel Ivanna Van Dijk karya Risa Saraswati dengan novel Ananta Prahadi karya Risa Saraswati memiliki kesamaan yaitu dominan pada nilai sosial hakikat manusia terhadap sesama dalam kehidupan bermasyarakat, sehingga mudah dipahami ceritanya. Perbedaan yang ada yaitu nilai social novel Ivana Van Dijk karya Risa Saraswati lebih cenderung kepada hakikat hubungan manusia yang menganggap hidup itu buruk sedangkan pada novel Ananta Prahadi cenderung kepada nilai sosial berupa hakikat hubungan manusia dengan sesamanya, diartikan bahwa berhubungan dengan orang lain merupakan sesuatu yang tidak baik atau bahkan hanya akan berdampak buruk dan dapat menghambat segala yang ingin ia lakukan, ia mengagap bahwa dapat menyelesaikan segala permasalahan dengan sendirinya tanpa memerlukan bantuan dari siapa pun. Selanjutnya, novel Ananta Prahadi, tidak mengarah pada cerita-cerita yang horor, berbeda dengan novel Ivana Van Dijk yang ceritanya mengandung cerita horor.
\end{abstract}

Kata kunci: perbandingan nilai sosial, novel, pendekatan sosiologi sastra

\section{COMPARISON OF SOCIAL VALUES BETWEEN IVANNA VAN DIJK NOVEL WITH ANANTA PRAHADI NOVEL BY RISA SARASWATI THROUGH THE SOCIOLOGICAL APPROACH}

\begin{abstract}
The purpose of this study was to describe the comparison of Ivanna Van Dijk novel by Risa Saraswati with the novel Ananta Prahadi by Risa Saraswati through a sociology approach. This research method is a qualitative descriptive research method. The research data is data in the form of words, phrase phrases or sentence which show social values in Ivanna Van Dijk novel by Risa Saraswati with the novel Ananta Prahadi by Risa Saraswati. Data analysis techniques by reducing data, presenting data, and drawing conclusions. The results showed that Ivanna Van Dijk novel by Risa Saraswati with the novel Ananta Prahadi by Risa Saraswati had similarities, namely dominant in the social value of human nature to others in social life, so that
\end{abstract}


the story was easy to understand. The difference is that the value of Ivana Van Dijk social novel by Risa Saraswati tends to be more about the nature of human relations which considers life to be bad while in Ananta Prahadi novels tends to social values in the form of human relations with each other, it means that dealing with others is something that is not good or even only will have a bad impact and can hinder everything he wants to do, he is amazed that it can solve all problems by itself without requiring help from anyone. Furthermore, Ananta Prahadi novel does not lead to horror stories, unlike the Ivana Van Dijk novel whose stories contain horror stories.

Keywords: comparison of social values, novels, the sociology approach to literature

\section{A. Pendahuluan}

Kata susastra sendiri pada hakikatnya berasal dari awalan su- yang berarti indah atau baik. Kata susastra sering dibandingkan dengan belles-letters (Teeuw, dalam Susanto, 2016:1). Begitu juga llyas (2011:163) menjelaskan bahwa kesustraan atau sastra adalah hasil karya manusia yang lebih menggunakan bahasa sebagai alat untuk menulis ataupun pencurahannya, sehingga dengan begitu dapat menimbulkan rasa indah (estetis) dan dapat membuat bergetar seluruh tali jiwa pembaca atau pendengarannya, baik lisan maupun tulisan.

Dengan demikian, sastra mempunyai tujuan salah satunya yaitu untuk menghasilkan sebuah karya sastra. Suatu karya sastra diciptakan oleh manusia sebagai kegiatan kreatif dan inovatif dalam bentuk lisan dan tulisan yang memiliki nilai keindahan yang tidak bisa dipisahkan dengan pengajaran bahasa. Hal ini dikarenakan karya sastra dan pengajaran bahasa saling melengkapi, terutama dalam pembelajaran bahasa, guru selalu menggunakan karya sastra sebagai objek utamanya dalam menjelaskan ciri dan fungsi suatu bahasa (Noermanzah, 2017:28). Banyak jenis karya sastra yang harus dikuasai oleh peserta didik, salah satunya adalah novel.

Novel merupakan sebuah karya sastra yang menceritakan kisah kehidupan seseorang, baik itu dalam kehidupan yang baik, maupun dalam kehidupan yang buruk, sehingga pembaca mendapat suatu pembelajaran dari sebuah kisah kehidupan, dan pembaca juga akan lebih peka terhadap sebuah kehidupan di sekelilingnya. Kosasih (2012:60) mengatakan "Novel adalah karya imajinatif yang mengisahkan sisi utuh atas problematika kehidupan seseorang atau beberapa orang tokoh". Selanjutnya, Sayuti (2000:6-7) mendefinisikan novel biasanya memungkinkan adanya penyajian secara meluas (exspands) tentang tempat atau 
ruang, sehingga tidak mengherankan jika keberadaan manusia dalam masyarakat selalu menjadi topik utama". Sedangkan menurut Tarigan (2011:167) novel adalah suatu cerita dengan suatu alur, cukup panjang mengisi suatu buku atau lebih, yang menggarap kehidupan pria dan wanita yang bersifat imajinatif.

Novel Ivanna Van Dijk karya Risa Saraswati menceritakan sesorang penulis yang mempunyai suatu kelebihan dengan bisa melihat hal gaib, dan salah satu karyanya yaitu novel Ivanna Van Dijk dimana penulis mengambil cerita dari hantu Belanda yang membuatnya penasaran sejak pertama kali hantu Belanda itu mengusir penulis dengan sangat kasar dan marah, semenjak itu penulis itu berusaha akan mengambil cerita dari sosok hantu yang pemarah itu, dan kemudian setelah beberapa kali mencoba untuk berdamai dengan hantu itu ternyata masih saja hantu itu tidak ingin berbicara, hanya tatapan yang sangat marah dan tajam yang ia lihatkan.

Pada akhirnya mulai sedikit penulis mencari tahu tentang sosok hantu itu dari berbagai hantu salah satunya Wiliam yang memberitahu tentang sosok hantu Belanda itu, dan informasi dari para hantu lainnya, Ivana Van Dijk merupakan gadis yang sangat tertekan dan dikucilkan oleh seluruh warga. Gara-gara hal tersebut Ivana menjadi sosok yang pendendam dan pemarah sehingga ingin membalas segala yang telah terjadi pada keluarganya. Hal ini berawal ketika adik laki-lakinya diberi nama Dimas. Setelah dendamnya terbalaskan, ia lebih dibenci oleh semua orang dan masyarakat sekitarnya, hingga ia meninggal pun para hantu enggan berteman dan bertemu dengannya karena Ivanna merupakan sosok hantu yang paling ditakutkan.

Berbeda halnya dengan novel Ananta Prahardi karya Risa Saraswati menceritakan percintaan seorang gadis yang bernama Tania. Kisah tersebut bermula dari persahabatan antara Tania, Ananta Prahardi, dan Piere. Tania adalah seorang gadis yang memiliki sikap yang keras kepala. Keluarganya tidak memperdulikannya sehingga Tania hidup dalam kesepian meskipun di tengahtengah keluarganya. Kesepian itu membuat Tania memiliki hobi suka melukis untuk menghibur diri, karena sikapnya kurang baik membuatnya dijauhi oleh teman-temanya. Selain itu, Tania memiliki kebiasaan yang tak sama dengan orang-orang lainnya. la hobi mengonsumsi nasi basi atau kerak yang sudah 
dijemur dibandingkan dengan makanan yang bisa dikunsumsi oleh orang-orang. Keanehannya itu membuat Tania sering diejek oleh teman-temannya.

Pada suatu hari ada anak baru di kelas Tania ia bernama Ananta, lambat laun akhirnya Tania dan Ananta menjadi sahabat yang mengakibatkan kebiasaan buruk Tania mulai menghilang, hingga Tania jatuh hati terhadap Ananta yang sangat baik terhadapnya, hingga lulus SMA akhirnya Ananta bekerja di toko lukisan Tania bahkan tinggal satu rumah dengannya. Beberapa waktu kemudian Ananta memperkenalkan Perre terhadap Tania karena ingin membawa salah satu lukisan Tania di galerinya hingga ternyata Perre menaruh perasaan terhadap Tania bahkan Tania pun sebaliknya. Novel ini lebih menceritakan sebuah hubungan percintaan antara Tania, Ananta Prahardi, dan Pierre.

Berdasarkan kedua sinopsis novel yang membahas tentang suatu kehidupan lingkungan dan masyarakat dalam hal ini, peneliti membandingkan nilai sosial pada Novel Ivanna Van Dijk Karya Risa Saraswati dengan Ananta Prahadi Karya Risa Saraswati. Endraswara (2014:9) menyatakan sastra bandingan merupakan kegiatan membandingkan sastra sebuah negara dengan negara lain atau dengan sastra bidang lain sebagai ungkapan kehidupan. Dalam penelitian ini yang menjadi fokus adalah perbandingan nilai sosial dalam novel Ananta Prahadi karya Risa Saraswati dan novel Ivana Van Dijk karya Risa Saraswati dengan pendekatan sosiologi sastra.

Nilai sosial adalah suatu hal yang dapat memanusiakan manusia atau bisa dikatakan juga kembali kepada fitrah manusia. Menurut Aisah (2015:4) nilai sosial adalah sesuatu yang menjadi ukuran dan penilaian pantas tidaknya suatu sikap yang ditunjukkan dalam kehidupan bermasyarakat. Young (dalam Laining, 2009:28) nilai sosial adalah asumsi abstrak dan sering tidak disadari mengenai apa yang dianggap benar dan yang penting. Nilai sosial lebih ditekankan sebagai petunjuk arah demi tercapainya tujuan sosial masyarakat. Nilai sosial juga dapat mendorong pembaca untuk dapat bersikap atau bertingkah laku ke arah yang lebih baik sehingga nilai sosial merupakan nilai yang mencerminkan suatu usaha dari setiap manusia untuk dapat menyesuaikan diri terhadap lingkungan sosialnya dan pengarang merupakan salah satu bagain dari masyarakat dengan 
kemampuan imajinasinya mampu mengekspresikan berbagai masalah kehidupan hadir di masyarakat sehingga pembaca dapat mengambil hikmah dari karya tersebut.

Novel karya Risa Saraswati pernah diteliti oleh Fitriany dkk. (2018:2) pada karyanya yang lain yaitu novel Gerbang Dialog Danur berkaitan dengan indigo dalam novel tersebut. Hasil penelitiannya menunjukkan bahwa bahwa kelebihan indigo dan kekurangan indigo ditemukan serta digambarkan dalam novel Gerbang Dialog Danur karya Risa Saraswati. Kemudian, pernah juga diteliti oleh Salim \& Sukirno (2017) dengan judul "Analisis sosiologi Sastra Novel Rasuk karya Risa Saraswati dan Rencana Pelaksanaanya di SMA". Hasil penelitian menunjukkan bahwa: (1) gambaran unsur-unsur intrinsik novel Rasuk karya Risa Saraswati, (2) Nilai sosiologi dalam novel lebih dominan pada cinta kasih sayang ibu pada anak, serta kasih sayang antar keluarga, sahabat dan saudara, (3) gambaran hubungan aspek ekonomi, sosial, moral dengan persaudaraan, dan (4) rencana pelaksanaan pembelajaran dengan metode STAD. Dari beberapa penelitian relevan dapat dijelaskan bahwa kajian perbandingan nilai sosial dalam novel Ananta Prahadi karya Risa Saraswati dengan novel Ivana Van Dijk karya Risa Saraswati dengan pendekatan sosiologi sastra, belum pernah diteliti.

\section{B. Metode Penelitian}

Metode penelitian yang digunakan adalah metode deskriptif kualitatif. Penelitian deskriptif kualitatif tidak diperlihatkan untuk menguji hipotesa tertentu, tetapi dalam penelitian ini hanya menggambarkan suatu "objek" tertentu tentang suatu fenomena atau kondisi. Sugihatuti (2016:15) menjelaskan bahwa kualitatif merupakan pendekatan penelitian naturalistik karena penelitianya dilakukan pada kondisi yang alamiah dan juga sebagai metode etnografis. Deskriptif merupakan penelitian yang diarahkan untuk memberikan gejala, fakta atau kejadian secara sistematis dan akurat, mengenai sifat populasi atau daerah tertentu (Riyanto, 2010:23).

Teknik pengumpulan data menggunakan teknik dokumentasi berupa novel Ivanna Van Dijk dan novel Ananta Prahadi karya Risa Saraswati. Sumber data dalam penelitian ini adalah novel Ivanna Van Dijk karya Risa Saraswati terdiri dari 
211 halaman dan novel Ananta Prahadi karya Risa Saraswati terdiri dari 246 halaman. Data penelitian yang digunakan yaitu berupa kutipan peristiwa yang mengandung nilai sosial berupa: a) hakikat hidup manusia, b) hakikat manusia dengan alam, dan c) hakikat hubungan manusia dengan sesama dalam novel Ivanna Van Dijk dan novel Ananta Prahadi karya Risa Saraswati. Teknik analisis data dilakukan dengan cara reduksi data, penyajian data, dan penarikan kesimpulan.

\section{Hasil Penelitian dan Pembahasan}

\section{Hasil Penelitian}

Hasil penelitian tentang perbandingan nilai sosial antara novel Ivanna Van Dijk dengan novel Ananta Prahadi karya Risa Saraswati malalui pendekatan sosiologi sastra, meliputi nilai berkaitan dengan hakikat hidup manusia, hakikat manusia dengan alam sekitar, dan hakikat hubungan manusia dengan sesama.

a. Nilai Sosial dalam Novel Ivana Van Dijk Karya Risa Saraswati

1) Nilai Hakikat Hidup Manusia

Novel Ivana Van Dijk karya Risa Saraswati merupakan novel yang menceritakan kisah kehidupan bermasyarakat yang kental dengan mitos dan kisahan misteri. Hal ini bisa dilihat dari kutipan cerita dimana tokoh Aku bertemu dengan sosok hantu Belanda yang sangat menakutkan, bahkan ia sering diplototi, ia merasakan ketakutan, dan ia takut tiba-tiba hantu itu datang. Akan tetapi, ia bingung untuk dapat menceritakan kejadian yang baru saja ia alami. Hal ini merupakan sesuatu yang buruk terlihat. Kutipan cerita tersebut dapat dilihat pada salah satu kutipan berikut.

(001)"rasanya ingin bercerita pada orang lain tapi aku sendiri tak tahu harus memulainya darimana"

Pada kutipan tersebut tergambar jika hakikat hidup manusia adalah mahluk sosial. Jadi, tanpa orang lain manusia akan kesulitan dalam menjalankan kehidupanya. Pada kutipan tersebut juga menganggap bahwa hidup itu buruk dan ia bingung ingin bercerita kepada siapa hanya saja tokoh ini tetap akan bercerita untuk menenangkan jiwanya. Oleh sebab itu, dalam kebimbangan tokoh Aku selalu bertemu dengan sosok hantu yang berada di sekitarnya, yang sebenarnya 
adalah rasa sepi yang tergambar seolah-olah manusia yang selalu mengamatinya. Dalam novel ini juga tergambar jelas bagaimana pengarang mengambarkan sisi sosial seseorang terhadap orang lain, sehingga pembaca terbawa dalam suasana tokoh dalam cerita.

2) Nilai Hakikat Hubungan Manusia dengan Alam Sekitar

Hubungan dengan alam sekitar merupakan hubungan yang paling kompleks dalam kehidupan seseorang. Seseorang tidak hanya berhubungan dengan sesama dan masyarakat, tetapi harus mampu menyesuaikan diri dengan lingkunganya. Dalam novel ini tokoh Aku merupakan tokoh yang gemar untuk menulis sebuah novel dan ketika hendak menulis novel Ivanna, ia merasa tidak bisa untuk menggambarkan cerita Ivanna, karena ia merasa takut akibat tokoh ini pernah diusir dan diplototin oleh hantu Ivanna. Dalam hal ini bagaimana tokoh harus menyesuaikan diri dengan alam sekitar dalam menemukan imajinasinya dalam menulis novel. Tokoh ini mendapat kendala dengan alam sekitar ketika menuangkan ide-idenya dalam sebuah karya sastra. Hal ini terlihat dalam salah satu kutipan novel berikut.

(020)"Rasa-rasanya aku ingin menyerah apakah sebaiknya ku tulis sosok lain saja?"

Berdasarkan kutipan tersebut tergambar pertentangan dengan dirinya terhadap lingkunganya, dalam hal ini sosok hantu sebagai bagian dari alam, tergambar bahwa penulis pasrah dan ia ingin menyerah terhadap apa yang ia alami saat ini, dengan keadaan yang menurutnya tidak mungkin akan terselesaikan. Selain itu, pertentangan dengan hubungan dengan alam sekitar juga tergambar ketika tokoh menutup laptop dan segera keluar dari kamar dan menuju lift, tokoh ini merasakan sesuatu, dan ia mengaggap bahwa ada sesuatu yang dasyat, tetapi tokoh ini masih mencoba untuk dapat mengatasinya. Hal ini dapat dilihat pada kutipan berikut.

(021) "Lorong menuju lift lantai ini rasanya membuat bulu kudukku berdiri. Kupejamkan mata batin ini, mencoba menolak siapa pun yang ingin muncul menyapaku".

Pada kutipan tersebut menggambarkan bahwa penulis pasrah akan keadaan, tetapi ia tetap akan mencoba melawan ketakutan yang ia alami, oleh karena itu penulis ini menganggap alam yang dapat ditahlukkan, dengan melawan 
rasa takut. Kutipan ini tergambar jika pertentangan terhadap dirinya dalam mengatasi rasa emosi dalam dirinya, mengatasi permasalahan yang muncul dalam lingkunganya, sehingga tidak menjadi momok yang selalu menghantuinya. 3) Nilai Hakikat Hubungan Manusia dengan Sesamanya

Hubungan dengan sesamanya cenderung lebih berhubungan dengan orang lain, tetapi dalam novel ini orang lain digambarkan dengan sosok hantu wanita Belanda. Hal ini dapat dilihat tokoh Aku ketika hendak tidur malam, tetapi dalam tidurnya selalu terbayang pada sosok hantu perempuan Belanda Ivanna dan akhirnya ia pun mencoba memanggilnya, dari sinilah diharapkan hantu yang kasar tadi dapat berdamai dengannya, yang terlihat pada kutipan berikut.

(032)"Ivanna..Ivanna...Datanglah" taka da yang datang seolah ia enggan menyapa"

Pada kutipan tersebut tergambar jika tokoh Aku berusaha ingin berinteraksi dengan sesama dalam hal ini tokoh hantu Ivana, tetapi interaksi tersebut masih engan diterima. Tokoh hantu Ivanna tidak ingin berhubungan dengan siapa pun, karena ia menganggap dirinya bisa hidup sendiri tanpa ketergantungan pada orang lain.

Selain itu, hubungan dengan sesama dapat dilihat pada salah satu kutipan dimana tokoh Aku berusaha untuk menjalin kembali persaudaraan dengan keluarganya. Akibat pertengkaran yang sangat hebat dengan adiknya tokoh Aku, yang tidak tau timbulnya amarah, sehingga ia memarahi adiknya dengan sangat kasar. la pun menyadari dan akhirnya dia putuskan untuk kembali ke rumah dan meminta maaf kepada sang adik untuk dapat mempertahankan hubungan yang baik dengan adiknya. Hal ini dapat dilihat pada salah satu kutipan berikut.

(033) Sepertinya aku harus kembali ke rumah, meminta maaf kepada adik semata wayangku itu.

Pada kutipan tersebut terlihat bahwa adanya hubungan sesama saudara yang harus terjalin dengan baik, sehingga dengan meminta maaf sebagai salah satu pengerat hubungan tersebut, dari kesalahan yang telah ia lakukan. Tokoh aku berusaha menjalin kembali rasa persaudaraan dengan keluarganya karena 
manusia hakikatnya adalah mahluk sosial, yang membutuhkan orang lain terutama keluarga dan saudara terdekat.

b. Nilai Sosial dalam Novel Ananta Prahadi Karya Risa Saraswati

1) Nilai Hakikat Hidup Manusia

Hakikat hidup manusia adalah memiliki prinsip dan pendirian dalam kehidupanya. Walau terkadang prinsip hidup bertentangan baik dengan diri sendiri, orang lain maupun alam sekitar. Dalam novel ini tergambar jika tokoh Tania merupakan tokoh yang mempunyai sifat aneh dibandingkan dengan temanteman yang lain atau bahkan orang lain. Apalagi ketika menyangkut sekolah yang memang banyak aturan yang harus dipatuhi, sehingga ia beranggapan bahwa hidup itu buruk. Prinsip hidup Tania bertentangan dengan orang lain dan lingkungannya sehingga seolah-olah sesuatu yang tidak sesuai dengan prinsipnya salah. Hal ini tergambar pada salah satu kutipan berikut.

(01) Aku tertuduk malas di bangku kelas. Seperti biasa, hari ini terasa begitu menjemukan. Lagi-lagi pelajaran tidak penting, Tata Busana. Seharusnya pelajaran ini dihapuskan dari muka bumi.

Pada kutipan di atas tergambar bagaimana tokoh Tania merasa tidak nyaman dengan lingkunganya dan sesuatu yang harus dijalaninya. Dari kutipan tersebut memang tergambar tokoh Aku menjadi orang yang sangat pemalas dan ia memang tidak suka dengan aturan-aturan, untuk hidup di dunia ini. Maka dari itu kutipan ini menganggap hidup itu buruk, di sisi lain tetap harus dijalaninya mesti mendapat pertentangan dari dirinya sendiri.

2) Nilai Hakikat Hubungan Manusia dengan Alam Sekitar

Hubungan dengan alam sekitar adalah hubungan tokoh dengan lingkunganya beraktivitas. Bagaimana tokoh berhubungan baik atau positif maupun negatif dengan alam sekitar. Dalam novel ini tergambar ketika tokoh mendapatkan permasalahan sehingga tempat mengadu adalah penguasa alam. Tokoh Aku berkeyakinan memiliki hubungan batin dengan alam sekitar sehingga ketika mendapat permasalahan tempat berserah diri adalah penguasa alam. Hal ini dapat dilihat dari salah satu kutipan: 
(024) Anantaaa!!lastaga, kenapa kamu? Apa yang terjadi kepadamu? Alam semesta tolong selamatkan Anta!! Aku berteriak saat beberapa orang anggota keluargaku mengerumuni Anta yang tak sadarkan diri di antara genangan darah.

Hubungan manusia dengan alam adalah hubungan dengan hati dan kepercayaanya, sehingga ketika terjadi permasalahan maupun sebagai tempat mengadu alam adalah tempat yang tepat menurut tokoh dalam novel ini. Pada kutipan tersebut digambarkan bahwa suatu kekuatan alam yang dasyat sehingga manusia hanya bisa pasrah dengan keadaan yang menimpa tokoh lainya. Hal ini merupakan sesuatu di luar dugaan ketika terjadi hal seperti itu. Ini membuktikan kaitan batin seseorang dengan alam sekitar tidak dapat terpisahkan. Hal ini juga dapat dilihat dari salah satu kutipan berikut.

(025) Anta? Anta? Kau bangunnn?? Anantaaa! Terima kasih alam semesta!! Aku berteriak histeris melihat Ananta tersenyum begitu lebar melihatku.

Pada kutipan tersebut terlihat bahwa suatu alam yang dasyat, tetapi masih dapat ditahlukan oleh manusia, hal ini ketika Ananta sedang sakit dan ia masih bisa sembuh oleh karena itu dianggap dapat menahlukkan kesakitan yang pernah dialaminya. Alam dipercaya secara batiniah memiliki ikatan batin yang kuat dengan tokoh yang ada dala novel tersebut.

3) Nilai Hakikat Hubungan Manusia dengan Sesamanya

Nilai sosial berupa hubungan manusia dengan sesamanya adalah hubungan yang vital dan tidak dapat terpisahkan. Manusia tidak akan bertahan dalam sebuah kehidupan tanpa bantuan sesamanya. Dalam novel ini terjadi konflik dalam diri tokoh utama dimana tokoh tersebut tidak memiliki hubungan yang baik dengan sesama. Tokoh utama selalu terkucilkan dari pergaulan dan hubungan dengan orang lain. Tokoh ini sering kali merasa kesepian dengan kehidupanya, hal ini dapat dilihat dari salah satu kutipan berikut.

(052) Di kelas ini, bahkan di sekolah ini aku tak memiliki seorang pun teman, bukan aku yang menutupi diri tetapi mereka semua menganggapku aneh dan gila.

Berdasarkan kutipan di atas, tergambar bahwa tidak ada hubungan yang baik antara sesama, dan inilah yang menyebabkan sulit untuk mempunyai teman karena dianggap seseorang yang berbeda. Tokoh dalam cerita ini merasa sulit menjalin hubungan dengan sesama karena perasaan berbeda dari dalam dirinya 
dengan orang lain. Begitu juga dengan lawan dari tokoh ini sulit menjalin hubungan yang baik karena tokoh Aku berbeda dengan mereka. Pertentangan ini membuat hubungan sesama terkesan tidak terjalin dengan baik. Hal ini juga terlihat dari salah satu kutipan berikut:

(053) Menurutku, ini adalah sesuatu yang baik. Karena bagiku, memiliki teman hanya melatih kita berbasa-basi, dan kurasa itu sunggh tak perlu.

Pada kutipan tersebut tergambar bahwa adanya hubungan dengan orang lain adalah sesuatu hal yang buruk karena ia menganggap bahwa dengan hidup sendiri tanpa teman akan lebih baik dan dapat menyelesaikan permasalahannya sendiri. Selain itu tergambar juga pada kutipan berikut.

(053) Aku lebih suka berdiam diri dan melukis sesuatu di dalam kamar, dibandingkan harus berinteraksi dengan orangtua, adik, dan kakakku.

Pada kutipan tersebut menggambarkan bahwa tokoh ini memang tidak ingin berinteraksi dengan orang lain. la hanyak menggagap orang lain itu membuatnya rumit. Oleh karena itu, ia lebih memilih untuk selalu sendiri. Dari beberapa kutipan tersebut dapat disimpulkan jika tokoh utama memiliki hubungan dengan sesama kurang baik. Tokoh utama memiliki prinsip hidup berbeda terhadap hubungan dengan sesama dikarenakan permasalahan pada masa lampau.

\section{Pembahasan}

Menolok novel Ivana Van Dijk dengan novel Ananta Prahadi karya Risa Saraswati melalui pendekatan sosiologi sastra, digambarkan jika persamaanya yaitu sama-sama merupakan pengarang yang sama yaitu Risa Saraswati dan merupakan novel terbarunya tahun 2018, serta hubungan manusia dengan sesama pada nilai sosial sama-sama kurangnya hubungan dengan orang lain yang kurang baik, sehingga kedua novel tersebut banyak mengalami permasalahan akibat kurang bersosial dengan orang lain.

Persamaan dari sisi isi novel adalah bagaimana pengarang mengambarkan tokoh dari setiap novel dengan gaya kehidupan yang kental dengan kehidupan bermasyarakat. Hubungan tokoh dengan orang lain yang tidak berjalan baik karena prinsip hidup yang berbeda dengan orang lain. Selain itu, persamaan dari sisi penulisan yang tidak banyak menggunakan bahasa kiasan sehingga mudah 
dipahami pembaca secara kasat mata. Dalam cerita kedua novel tersebut juga memiliki kesamaan jenis novel yaitu sama-sama bergenre misteri. Kedua novel tersebut disajikan dengan pola-pola kalimat yang runtun sehingga tidak memunculkan makna ambiguitas, secara keseluruhan isi dan bahasa kedua novel sama-sama memiliki kualitas yang baik.

Berdasarkan hasil analisis diketahui juga perbedaan kedua novel tersebut yaitu:, nilai sosialnya novel Ivana Van Dijk karya Risa Saraswati lebih cenderung kepada hakikat hubungan manusia yang menganggap hidup itu buruk dan menganggap bahwa suatu kehidupan itu buruk karena pada novel ini banyak mengalami penderitaan dan cacian pada masyarakat setempat, hingga timbulnya Tokoh Ivanna ingin membalas dendam. Sedangkan pada novel Ananta Prahadi karya Risa Saraswati cenderung kepada nilai sosial berupa hakikat hubungan manusia dengan sesamanya, yang diartikan bahwa berhubungan dengan orang lain merupakan sesuatu yang tidak baik atau bahkan hanya akan berdampak buruk dan dapat mengacaukan atau menghambat segala yang ingin ia lakukan. la mengagap bahwa dapat menyelesaikan segala permasalahan dengan sendirinya tanpa memerlukan bantuan dari siapa pun. Perbedaan selanjutanya yaitu novel Ananta Prahadi karya Risa Saraswati, tidak mengarah pada cerita-cerita yang horor, berbeda dengan novel Ivana Van Dijk karya Risa Saraswati yang ceritannya mengandung cerita horor, dilihat dari segi alaurnya novel Ivanna Van Dijk menggunakan alur mundur Ananta Prahadi menggunakan dan novel alur maju.

Berdasarkan hasil analisis menolok novel Ananta Prahadi dengan novel Ivana Van Dijk karya Risa Saraswati, diketahui jika kedua novel tersebut sangat kental dengan nilai-nilai sosial kemasyarakatan, yang bersentuhan langsung dengan prinsip hidup seseorang baik dengan diri sendiri, alam sekitar maupun sesama. Kedua novel mengambarkan bagaimana pengarang mengolah setiap kata dan kalimat dengan apik sehingga mudah dipahami setiap pembaca. Pesan disampaikan secara langsung oleh pengarang melalui kalimat dalam novel. Cerita yang disajikan sesuai dengan semua umur pembaca, baik remaja maupun pembaca dewasa. Secara keseluruhan novel Ananta Prahadi dengan novel Ivana 
Van Dijk karya Risa Saraswati memiliki persamaan dan perbedaan yang cukup kompleks, tetapi tidak menghilangkan makna yang ingin disampaikan pengarang.

Penelitian ini relevan dengan penelitian oleh Salim \& Sukirno (2017) dengan judul "Analisis sosiologi Sastra Novel Rasuk karya Risa Saraswati dan Rencana Pelaksanaanya di SMA". Hasil penelitian menunjukkan bahwa: (1) gambaran unsur-unsur intrinsik novel Rasuk karya Risa Saraswati, (2) Nilai sosiologi dalam novel lebih dominan pada cinta kasih sayang ibu pada anak, serta kasih sayang antar keluarga, sahabat dan saudara, (3) gambaran hubungan aspek ekonomi, sosial, moral dengan persaudaraan, dan (4) rencana pelaksanaan pembelajaran dengan metode STAD. Berdasarkan hasil penelitian relevan diketahui persamaannya yaitu: (1) memiliki persamaan dari segi pengarangnya; (2) memiliki kesamaan dari sisi alur ceritanya; dan (3) memiliki kesamaan dari gambaran nilai-nilai sosialnya. Sedangkan perbedaannya yaitu: (1) kedua penelitian memiliki perbedaan objek novelnya, jika penulis menggunakan dua novel maka penelitian relevan menggunakan satu nove dan (2) penulis lebih menitikberatkan pada perbedaan dan persamaan kedua novel karya Risa Saraswati sedangkan penelitian relevan lebih menitikberatkan pada aplikasi pembelajaran di sekolah.

Berdasarkan penjelasan di atas tergambar jika penelitian yang penulis lakukan memberikan gambaran dari sisi nilai sosial kedua novel sehingga mampu dicari persamaan dan perbedaanya. Penulis lebih memfokuskan pada perbedaan nilai sosial dikarenakan tertarik dengan alur-alur novel yang digambarkan oleh Risa Saraswati yang lebih condong ke genre horor atau misteri. Selain itu, dengan pengambaran nilai-nilai sosial ini akan mempermudah pembaca dalam memahami isi novel secara keseluruhan. Jadi, dapat disimpulkan jika novel Ananta Prahadi dengan novel Ivana Van Dijk karya Risa Saraswati memiliki perbedaan dari pengambaran nilai-nilai sosialnya.

\section{Simpulan}

Berdasarkan analisis nilai social yang sudah dilakukan pada novel Ivanna Van Dijk dan novel Ananta Prahadi karya Risa Saraswati melalui pendekatan sosial dapat disimpulkan bentuk nilai sosial meliputi: hakikat hidup manusia 27 
kutipan, hakikat manusia terhadap alam sekitar 35 kutipan, hakikat manusia terhadap sesama 49 kutipan, sedangkan novel Ananta Prahadi karya Risa Saraswati: nilai hakikat hidup manusia 32 kutipan, hakikat manusia terhadap alam sekitar 29 kutipan, hakikat manusia terhadap sesama 54 kutipan. Hasil perbandingan pada kedua novel tersebut yaitu persamaan novel Ivana Van Dijk dengan novel Ananta Prahadi karya Risa Saraswati, yaitu sama-sama pengarang yang sama yaitu Risa Saraswati dan merupakan novel terbarunya tahun 2018, serta dari sisi isi cerita yaitu hubungan manusia dengan sesama pada nilai sosial sama-sama kurangnya hubungan dengan orang lain yang kurang baik.

Perbedaan yang ada yaitu novel Ananta Prahadi karya Risa Saraswati jumlah halamannya lebih banyak dibandingkan dengan novel Ivana Van Dijk karya Risa Saraswati. Nilai sosialnya novel Ivana Van Dijk karya Risa Saraswati lebih cenderung kepada hakikat hubungan manusia yang menganggap hidup itu buruk karena tokoh utama banyak mengalami penderitaan dan cacian pada masyarakat setempat, dari sinilah timbulnya Tokoh Ivanna ingin membalas dendam. Sedangkan pada novel Ananta Prahadi karya Risa Saraswati cenderung kepada nilai sosial berupa hakikat hubungan manusia dengan sesamanya, diartikan bahwa berhubungan dengan orang lain merupakan sesuatu yang tidak baik atau bahkan hanya akan berdapak buruk dan dapat mengacaukan atau menghambat segala yang ingin ia lakukan. la mengagap bahwa ia dapat menyelesaikan segala permasalahan dengan sendirinya tanpa memerlukan bantuan dari siapa pun. Selanjutanya, yaitu novel Ananta Prahadi tidak mengarah pada cerita-cerita yang horor, berbeda dengan novel Ivana Van Dijk ceritannya mengandung cerita horor.

\section{Daftar Pustaka}

Aisah, S. (2015). Nilai-Nilai Sosial yang Tergantung dalam Cerita Rakyat "Eence Sulaiman" pada Masyarakat Tomia. Jurnal Humanika, 15(3).

Endraswara, S. (2014). Sastra Bandingan. Jakarta: Bukupop.

Fitriany, D. A., Emzir, E., \& Lustyantie, N. (2018). Understanding Indigo through Novel Gerbang Dialog Danur by Risa Saraswati: A Study of Psychology Literary. Humanus, 17(1), 1. doi:10.24036/humanus.v17i1.8682 
llyas, N. (2011). Inti Sari dan Soal Bahasa dan Sastra Indonesia. Jakarta: PT. Bumi Aksara.

Kosasih, E. (2012). Dasar-Dasar Keterampilan Bersastra. Bandung: Yrama Widya.

Laining. (2009). Sosiologi. Jakarta: Pusat Pembukuan Depertemen Pendidikan Nasional.

Noermanzah, N. N. (2017). Plot in a Collection of Short Stories "Sakinah Bersamamu" Works of Asma Nadia with Feminimism Analysis. Humanus, 16(1), 27. doi:10.24036/jh.v16i1.7015

Riyanto, Y. (2010). Metodologi Penelitian Pendidikan. Surabaya: SIC.

Salim, N. N. \& Sukirno, S. (2017). Analisis Sosiologi Sastra Novel Rasuk Karya Risa Saraswati dan Rencana Pelakasanaan Pembelajarannya di SMA. Surya Bahtera, 5 (47), http://ejournal.umpwr.ac.id/index.php/suryabahtera/article/view/4745

Sayuti, S. A. (2000). Berkenalan dengan Prosa Fiksi. Yogyakarta: Gama Media.

Sugihastuti, S. S. (2016). Buku Ajar Bahasa Indonesia Akademik. Yogyakarta: Pustaka Pelajar.

Susanto, D. (2016). Pengantar Kajian Sastra. Yogyakarta: PT Buku Seru.

Tarigan, H. G. (2011). Prinsip-Prinsip Dasar Sastra. Bandung: Angkasa. 